\title{
Effect of Ramadan Fasting on Total cholesterol (TC) Low density lipoprotein cholesterol (LDL-C) and High density lipoprotein cholesterol (HDL-C) in Healthy Adult Male
}

\author{
Tanzin Ara Begum ${ }^{1}$, Nasim Jahan², Nayma Sultana ${ }^{3}$, Rama Choudhury ${ }^{4}$, Tahmina Yeasmin $^{5}$
}

\begin{abstract}
Background: Ramadan fasting has some effects on anthropometric, metabolic and physiological functions in the healthy subjects. Objective: To observe the effects of Ramadan fasting on serum total cholesterol (TC) low density lipoprotein cholesterol (LDL-C) and high density lipoprotein cholesterol(HDL-C) in healthy adult male. Methods: This prospective observational study was carried out in the Department of Physiology, Sir Salimullah Medical College (SSMC), Dhaka between January and December 2013. Sixty healthy adult male aged 24 to 28 years were studied. Serum TC, LDL-C and HDL-C levels were estimated by enzyme method. Data were collected twice; 1-3 days before Ramadan fasting (BRF) and then during $25^{\text {th }}-27^{\text {th }}$ days of Ramadan fasting (ARF) and compared. The statistical analysis was done by paired sample ' $t$ ' test. Results: In this study, the mean body weight (BW), BMI, TC, LDL-C levels were significantly $(\mathrm{p}<0.001)$ decreased, and HDL-C level was significantly $(\mathrm{p}<0.001)$ increased in ARF than BRF. Conclusion: The results of this study revealed that Ramadan fasting has some beneficial effects on cholesterol and lipoprotein status in healthy adult male.
\end{abstract}

Key words: Ramadan month, Ramadan fasting, lipid profile.

J Bangladesh Soc Physiol. 2015, December; 10(2): 46-50 For Authors Affiliation, see end of text.

http://www.banglajol.info/index.php/JBSP

\section{Introduction}

$\mathbf{T}$ he word Ramadan comes from the Arabic root ramida or ar-ramad, which means scorching heat or dryness ${ }^{1}$. Holy

Ramadan is the ninth month in the lunar calendar ${ }^{2}$. It lasts 29-30 days based on visual sightings of the crescent moon ${ }^{1}$. Ramadan is observed by over 400 million of Muslims throughout the world. Ramadan teach muslims self-restraint and remind them of the feeling of the impoverished ${ }^{3}$.

During the month of Ramadan, adult Muslims abstain from food, drink, smoking each day from dawn to sunset ${ }^{2}$. They take two meals per day,

Received June 2015; $\quad$ Accepted August 2015
Iftar at sunset and Sehri before dawn ${ }^{4}$. The duration of daily fasting varies due to geographic location of the country and the season when Ramadan fall as lunar calendar moves forward by about 11 days every year and it lasts about 12 to19 hours each day 5 .

This religious practice of fasting has been shown to play some role in protecting obesity and its related complications such as cardiovascular, hypertension and diabetes mellitus ${ }^{6-7}$.

Metabolism is sum of all chemical and physical changes that take place within the body and enable its continued growth and functioning. Ramadan fasting can induce different metabolic changes due to ingestion of nutrient at an unusual 
time and also affect on anthropometric measurements of people ${ }^{8}$. Usually during this month food frequency and quantity, sleep duration at night and daily physical activities are reduced $^{9}$. Again, Ramadan fasting is the nonpharmacological method for improving lipid profile ${ }^{4}$. However, healthy balanced diet consumption with plenty of fluid intake in Ramadan month can fulfill daily requirements in normal weight persons and provides excellent opportunity to shed excess weight and thus maintain suitable life style in over weight persons ${ }^{10}$.

It has been observed that body weight (BW) and body mass index (BMI) were significantly reduced after Ramadan fasting 5,8,11,12 . Similarly, some investigators observed that mean serum TC and LDL-C levels were significantly decreased whereas, HDL-C was significantly increased ${ }^{11,13}$. In contrast, some other researchers found significant increased levels of serum TC and LDL-C with significant decreased level of HDL$\mathrm{C}$ in healthy subjects at the end of Ramadan. Consumption of more dietary fat and cholesterol may be responsible for this inconsistency ${ }^{14}$

Increased incidence of Metabolic diseases resulting from increased rate of urbanization, have been reported. Hypertension, diabetes mellitus, dyslipidemia, coronary heart disease, cerebrovascular disease etc. are not uncommon in young adult. Ramadan fasting induce many physiological and psychological changes due to change in life style during Ramadan which may influence the metabolic reaction of the body. But little is known about this changes. Therefore, the present study has been designed to observe the effect of Ramadan fasting on some lipid and lipoprotein parameters in healthy adult male.

\section{Methods}

This prospective interventional study was carried out in the Department of Physiology, Sir Salimullah Medical College (SSMC), Dhaka between January and December 2013. Subjects were selected by following simple random sampling procedure. The protocol of this study was approved by Institutional Ethics Committee (IEC) of SSMC. Sixty healthy adult male subjects, aged 24-28 years were selected among intern doctors of Sir Salimullah Medical College and Mitford Hospital, Dhaka who were fasting for the whole month of Ramadan. They were studied once 1- 3 days before beginning Ramadan and also during $25^{\text {th }}-27^{\text {th }}$ days of Ramadan fasting. Subjects having history of hypertension, heart diseases, diabetes mellitus, renal diseases, thyroid diseases, liver diseases, mental disorders, smokers and alcohol users were excluded from the study. After proper counseling the aim, objectives, benefit, risk and procedure of the study were explained in details to the subjects. Informed written consents were taken from each subject. Subsequently a detailed family, personal, medical and dietary history was taken. Dietary history was taken as 5 meals/day (breakfast, two tiffin, lunch and dinner) from 1-3 days before Ramadan fasting and 3 meals/day (Iftar, dinner and Sehri) from $25^{\text {th }}-27^{\text {th }}$ days of Ramadan month. All the information and data were recorded in a prefixed data schedule.

Before Ramadan after an overnight fasting for 8-10 hours and during Ramadan month after 810 hours day time fasting, $5 \mathrm{ml}$ of venous blood was drawn from median cubital vein by sterile disposable syringe. Serum TC, LDL-C and HDL$C$ levels were estimated by enzyme method in the laboratory of Department of Physiology, Sir Salimullah Medical College. Data were expressed as mean $\pm \mathrm{SE}$ and were analyzed by paired sample ' $t$ ' test. $p$ value $<0.05$ was taken as level of significance.

\section{Results}

In this study, mean body weight (BW) and BMI were significantly $(\mathrm{p}<0.001)$ decreased in ARF than those of BRF. (Table I) The serum levels of TC and LDL-C were significantly $(p<0.001)$ decreased whereas, HDL-C level was significantly $(\mathrm{p}<0.001)$ increased in ARF than those of BRF. (Table II). 
Table I: Body weight (BW) and body mass index (BMI) in Study subjects $(\mathrm{n}=60)$

\begin{tabular}{lcc}
\hline Parameters & BRF & ARF \\
\hline Body weight $(\mathrm{kg})$ & $61.51 \pm$ & $58.97 \pm$ \\
& 1.91 & $1.93 * * *$ \\
BMI $\left(\mathrm{kg} / \mathrm{m}^{2}\right)$ & 21.48 & $20.59 \pm$ \\
& \pm 1.09 & $1.07 * * *$ \\
\hline
\end{tabular}

Data are expressed as mean \pm SE. For statistical analysis, paired sample ' $t$ ' test was performed for comparison between the phases. $\mathrm{BRF}=$ Before Ramadan fasting (1-3 days). $A R F=A t$ the end of Ramadan fasting $\left(25^{\text {th }}-27^{\text {th }}\right.$ days $) .(* * * p<0.001) n=$ Total number of subjects.

Table II: Serum TC, LDL-C and HDL-C levels in study subjects $(\mathrm{n}=60)$

\begin{tabular}{lcc}
\hline Parameters $(\mathrm{mg} / \mathrm{dl})$ & BRF & ARF \\
\hline Serum TC & 173.57 & 165.90 \\
& \pm 1.24 & $\pm 1.19 * * *$ \\
Serum LDL-C & 103.92 & 96.82 \\
& \pm 1.52 & $\pm 1.45 * * *$ \\
Serum HDL-C & \pm 0.51 & 54.97 \\
& $\pm 0.44 * * *$ & 47.70 \\
\hline
\end{tabular}

Data are expressed as mean $\pm \mathrm{SE}$. For statistical analysis, paired sample ' $t$ ' test was performed $. \mathrm{BRF}=$ Before Ramadan fasting (1-3 days). $\mathrm{ARF}=\mathrm{At}$ the end of Ramadan fasting $\left(25^{\text {th }}-27^{\text {th }}\right.$ days). $(* * *=p<0.001)$. $\mathrm{n}=$ Total number of subjects.

\section{Discussion}

In this study, the serum levels of TC and LDL-C were significantly decreased in ARF than those of BRF. The HDL-C level was significantly increased in ARF comparison to that of BRF.

This findings are similar with some other researchers ${ }^{11,13}$. In contrast, some investigators found significant increased levels of serum TC and LDL in healthy subjects at the end of Ramadan. Consumption of more dietary fat and cholesterol may be responsible for this inconsistency ${ }^{14}$. Significant decrease in HDL level was observed by some other researchers at 26th day of Ramadan. This discrepancy may be due to consumption of high carbohydrate diets along with less physical activities by the subjects ${ }^{9}$.

It has been suggested that, low fat and low calorie diet intake in Ramadan fasting decrease serum $\mathrm{TC}$ and LDL-C levels ${ }^{15}$. Efficient utilization of fat and decrease in basal metabolic rate (BMR) during Ramadan fasting decrease serum TC and LDL-C levels ${ }^{16}$. Again, lower availability of acetyl-CoA and glycerol along with decrease in the activity of dehydrogenases of pentose phosphate pathway reduce fat biosynthesis ${ }^{17}$. More consumption of legumes, cereals (wheat, bread) and fruits (rich in antioxidants), fish rich in omega-3 PUFA, during Ramadan fasting decrease serum LDL-C level and increase serum HDL-C levels thus reduce the risk of atherosclerosis and cardiovascular diseases ${ }^{18}$. Again, during month of Ramadan taking of one large evening meal positively affects the composition of plasma lipids, increased serum HDL-C level ${ }^{19}$. In addition, increased serum level of HDL-C in Ramadan fasting contributes to weight loss ${ }^{14}$.

During Ramadan fasting low calorie intake, behavioral modification of eating pattern and exercise in religious activities may be the factor that control obesity. In this month, extra lengthy prayer in every night is a sufficient exertion on the fasting individuals which is considered moderate exercise level ${ }^{8}$. The improved psychophysiological status might helpful in improving the life style related disorders like obesity, hypertension, diabetes and metabolic syndrome ${ }^{20}$.

In the present study, the decreased BW and BMI in healthy adult male in Ramadan month may be due to decreased number of meals especially loss of midday meal when the body is metabolically active and reduction of calorie intake. Again, the 
psycho-physiological well being might played important role in improving blood lipids supported by decrease serum TC and LDL-C levels which are the risk factors of atherosclerosis and increase serum HDL-C level which is the protective factors against development of atherosclerosis and cardiovascular diseases. In addition, taking of one large evening daily meal only by the study subjects increase serum HDL$\mathrm{C}$ level which is evident from their dietary history.

\section{Conclusion}

From this study, it can be concluded that, Ramadan fasting may induce benefits on blood cholesterol and lipoprotein levels by reducing bad cholesterol (LDL-C) and increasing good cholesterol (HDL-C) level and also may reduce obesity.

\section{Conflict of interest: None}

\section{Author Affiliation}

*1. Tanzin Ara, Assistant professor, Department of Physiology, Bangladesh Medical College, Bangladesh. E-mail: tanzi_n2@yahoo.com

2. Nasim Jahan, Professor, Department of Physiology, Sir Sallimullah Medical College, Mitford, Dhaka. E-mail: prof.dr.nasimjahan@gmail.com

3. Nayma Sultana, Professor, Department of Physiology, Sir Sallimullah Medical College, Mitford, Dhaka. Email:nayma_sultana@yahoo,com

4. Rama Choudhury, Associate Professor, Department of Physiology, Sir Sallimullah Medical College, Mitford, Dhaka. E-mail: mihirck2008@gmail.com

5. Tahmina Yeasmin, Associate Professor, Department of Physiology, Sir Sallimullah Medical College, Mitford, Dhaka. E-mail: mohshaque1@gmail.com

*For correspondence

\section{References}

1. Habaj MI and Hussain A. Sahih Musim (The book of fasting). hadith collection.com. 2012; 006: 2378.

2. Sarraf-Zadegan N, Atashi M, Naderi GA, Baghai AM, Asgary S, Fatehifar MR, Samarian H, Zarei M. Ramadan on the values and interrelations between biochemical, coagulation and haematological factors. Ann Saudi Med 2000; 20 (5-6): 377-381.

3. Al Hourani HM, Atoum MF, Akel S, Hijjawi N, Sally A. Effect of Ramadan fasting on some haematological and biochemical parameters. JJBS 2009; 2 (3): 103-108.
4. Saleh SA, Elsharouni SA, Cherian B. Mourou M. Effects of Ramadan fasting on waist circumference, blood pressure, lipid profile and blood sugar on a sample of healthy Kuwaiti men and women. Mal J Nutr 2005; 11(2): 143-150.

5. Mansi K, Amneh M. Impact of Ramadan fasting on metabolism and on serum levels of some hormones among healthy Jordanian students. J. Med. Sci 2007; 7(5): 755-761.

6. Hussaini MM, Sakr AH. Food and nutrition manual. Illinois. 1981; 345: 18-22.

7. Khan A, Khattak MMAK. Islamic fasting: An effective strategy for prevention and control of obesity. Pak J nutr 2002; 1(4): 185-187.

8. Unalacak M, Kara IH, Baltaci D, Erdem O Bucaktepe GE. Effect of Ramadan fasting on biochemical and haematological parameters and cytokines in healthy and obese individuals. Metab syndr and relat disord 2011; 9(2): 157-161.

9. Ziaee V, Razael M, Ahmadinejad Z, Shalkh H, Yousefi R, Tarmohammadi L, Bozorgi F, Behjati MJ. The changes of metabolic profile and weight during Ramadan fasting. Singapore Med J 2006; 47(5): 409-414.

10. Khaled BM, Belbraouet S. Effect of Ramadan fasting on anthropometric parameters and food consumption in 276 type diabetes obese women. Int J Diabetes Dev Ctries 2009; 29(2): 62-68.

11. Nematy M, Alinezhad-Namaghi M, Rashed MM, Mozhdehifard M, Sajjadi SS, Akhlaghi S, Sabery MR, Mohajeri SAR, Shalaey N, Moohebati M, Norouzy A. Effects of Ramadan fasting on cardiovascular risk factors: a prospective observational study. Nutr J 2012; 11: 1-7.

12. Rahman M, Rashid M, Basher S, Sultana S, Nomani, MZA. Improved serum HDL cholesterol profile among Banglaadeshi male students during Ramadan fasting. East Mediterr health J 2004; 10 (1-2): 131-137.

13. Mirzaei B, Rahmani-Nia F, Moghadam MG, Ziyaolhagh SJ, Rezaei A. The effect of Ramadan fasting on biochemical and performance parameters in collegiate wrestlers. Iran J Basic Med Sci 2012; 15(6): 1215-1220.

14. El-Taher AM. Zabut BM. Effect of Ramdan fasting on anthropometric measures and some biochemical parameters among type 2 diabetic patient in Gaza 
Governorate, Gaza Strip. IUG Journal of Natural and Engineering Studies 2013; 21(1): 25-40.

15. Afrasiabi A, Hassanadeh S, Sattarivand R, Nouri M, Mahboob S. Effect of fat and low calorie diet on plasma lipid levels in the fasting month of Ramadan. Saudi Med J 2003; 24 (2): 184-188.

16. Nomani MZA, Dietary fat, blood cholesterol and uric acid levels during Ramadan fasting. Inter J. Ramadan Res 1997; 1:1-6.

17. Mayes PA, Botham KM. Lipids of physiologic significance. In: Murry, R.K. Granner, D.K. Rodwell, V.M. (eds.). Harper's Illustrated Biochemistry. $26^{\text {th }} \mathrm{ed}$. UK. McGraw-Hill Companies Inc. 2006; 121-131.
18. Lamri-Senhadji MY, Ei Kebir B, Belleville J, Bouchenak M. Assessment of dietary consumption and time-course of changes in serum lipids and lipoproteins before, during and after Ramadan in young Algerian adults. Singapore Med J 2009; 50(3): 288-294.

19. Maislos M, Khamaysi N, Assali A, Abu-Rabiah Y, Zvili I, Shany S. Marked increase in plasma high-density lipoprotein cholesterol after prolonged fasting during Ramadan. Am J Clin Nutr 1993 ; 57: 640-2

20. Jaleel MA, Fathima FN, Bushra Jaleel NF. Journal of medical nutrition \& Nutraceuticals. J Med Nutr Nutraceut 2013; 2: 63-68. 